Reprod. Nutr. Dévelop., 1981, 21 (6B), 1095-1103.

\title{
Changes in the characteristics of turkey ejaculated semen and ductus deferens semen with repeated ejaculations
}

by M. R. BAKST, Helene C. CECIL

\author{
U.S. Deparfment of Agriculfure, SEA-AR \\ Avion Physiology Laboratory \\ Beltsville, Maryland 20705, U.S.A.
}

Summary. Studies were conducted to assess $(a)$ the $\mathrm{pH}$ and motility of semen removed from the ductus (d.) deferens and receptaculum from males sexually rested $1 \mathrm{wk},(b)$ the $\mathrm{pH}$, motility, and sperm concentration of semen after each successive ejaculation (ejaculated 3 or 5 times at 30-60 min intervals) and (c) the rate of semen replenishment and the fertility of the replenished semen after emptying the $d$. deferens by repeated ejaculations.

In both Large and Small White furkeys, the $\mathrm{pH}$ of the semen decreased progressively from the proximal segment of the $d$. deferens to the receptaculum. Sperm from all segments of the d. deferens were motile. With multiple ejaculations, the $\mathrm{pH}$ of successive ejaculates increased. Sperm concentration in the first and second ejaculates were the same, but the concentration in the third ejaculate was reduced. After 5 successive ejaculations $0.08 \mathrm{ml}$ (12 p. 100 of the total volume of the 5 ejaculations) remained in the d. deferens. After the 5 successive ejaculations the semen volume in the $d$. deferens was replenished between 4 and 5 days and the total sperm number was replenished within 3 days.

Before ejaculation the fertility of semen from the proximal and distal $d$. deferens was equal to the fertility of the first ejaculate. After multiple ejaculations, the fertility of the third ejaculate was slightly less than the fertility of the first ejaculate. The fertility of semen collected from d. deferens $24 \mathrm{hr}$ after multiple ejaculations was lower in the first of 2 fertility trials, but was not reduced in the 2 nd trial. However, in both trials the fertility of semen collected from the $d$. deferens 72 hrs after 5 successive ejaculations, was the same as fertility of the first ejaculate.

\section{Introduction.}

High quality turkey semen is imperative for a successful artificial insemination program and the economic benefits of using males on a high frequency semen-collection schedule has been recognized. In experiments to determine the optimum frequency of semen collection from turkey males Lorenz, Wilson, and Asmundson (1955) reported comparable semen volumes when collecled once a wk or every other day. However, the volume of semen per sample decreased gradually with daily collection. This decrease in semen volume with daily collection was confirmed by McCartney ef al. (1958). No decrease in sperm concentration or fertility was associated with the decrease in semen volume during daily collections. Collecting semen 3 days a wk with one day between collections has been recommended as practical for most turkey artificial insemination programs (Cooper, 1977). 
Little is known about the efficiency of semen collection (volume ejaculated to volume remaining in the ductus deferens) and the time required to refill the ductus deferens (d. deferens). Also, little is known about the characteristics of ejaculated semen and $d$. deferens semen after successive and/or exhaustive ejaculations.

The object of the present study was to assess $(a) \mathrm{pH}$ and motility of semen removed from the proximal, middle, distal, and receptaculum segments of the $d$. deferens from males sexually rested $1 \mathrm{wk},(b) \mathrm{pH}$, motility, and sperm concentration after each successive ejaculation (ejaculated 3-5 times at 30-60 min intervals), and (c) the rate of semen replenishment in the $d$. deferens and the fertility of replenished $d$. deferens semen after emptying the $d$. deferens by repeated ejaculations.

\section{Materials and methods.}

Yearling breeder male Diamond Hybrid Small White (SW) turkeys and Nicholas Large White (LW) turkeys (male and female lines) were housed separately in floor pens, provided feed and water ad libitum and exposed to a minimum of $14 \mathrm{hr}$ light per day. All males were ejaculated once or 3 times/wk for at least 6 wk and then given a 1 wk rest before the onset of these studies.

Multiple ejaculations. - Semen was collected by abdominal massage either once or 3 to 5 times at 30-60 min intervals. Each collection consisted of 3 to 4 « milkings » of the ejaculatory ducts into a $17 \times 119 \mathrm{~mm}$ conical test tube graduated in $0.1 \mathrm{ml}$. Semen volume, $\mathrm{pH}$, and motility were determined within 5 min of ejaculation. For sperm motility measurements a drop of semen was placed on a glass slide, diluted with a drop of diluent, and covered with a coverslip. Progressive motility was evaluated using a phase contrast microscope at a magnification of $400 \mathrm{X}$. Several areas of the coverslip were examined and the relative number of sperm moving vigorously forward was estimated. The scoring was 5 for $>90$ p. 100 sperm moving forward ; 4 for $70-89$ p. $100 ; 3$ for 40 69 p. $100 ; 2$ for $20-39$ p. $100 ; 1$ for $<20$ p. 100 , and 0 for no progressive motility. pH was determined on the undiluted semen with a flat-surface $\mathrm{pH}$ electrode (Orion) ( ${ }^{1}$ ) designed specifically for small volumes. The electrode surface was placed directly on the drop of undiluted semen and kept in place until the hundredth unit on the $\mathrm{pH}$ meter (Corning Digital 110) digital display unit stabilized for about $12 \mathrm{sec}$ at which time the $\mathrm{pH}$ was read. The $\mathrm{pH}$ electrode was checked regularly for accuracy in a standard $\mathrm{pH}$ solution. Sperm concentration was determined by optical density measurement using a Klett colorimeter.

D. deferens semen. - Males were killed by cervical dislocation at specific times after single or multiple ejaculations. The reproductive tract including the testes and cloaca was removed and connective tissue removed. The $d$. deferens was subdivided into the proximal, middle, and distal segments with each segment equivalent to $1 / 3$ the overall length of the tract. In those instances where the receptaculum (a sac-like dila-

(1) Mention of a trade name, proprietary product, or specific equipment does not constitute a guarantee or warranty by the U.S. Department of Agriculture and does not imply its approval by the exclusion of other products that may be suitable. 
tion of the $d$. deferens embedded in the facia and muscle around the cloaca) was not considered separately, it was incorporated with the distal d. deferens. Removal of semen from each of the segments was as follows: One end of the segment was grasped by forceps and the other end was placed in a graduated test fube. The thumb and forefinger of the free hand gently expressed the semen from the $d$. deferens into the test tube. This procedure was repeated until all the semen was removed. Semen volume, $\mathrm{pH}$, sperm motility, and concentration was then determined as described for the ejaculated semen.

Fertility. - The fertilizing capacity of ejaculated and d. deferens semen was determined by diluting pooled semen 1:1 with Beltsville Poultry Semen Extender (Sexton, 1980) and inseminating 6-9 hens/treatment at 2 wk intervals with an aliquot of the diluted semen containing $200 \times 10^{6}$ sperm/insemination dose. Eggs were collected daily and set weekly. On Day 7 of incubation the eggs were candled for viable embryos ; the percent fertility was calculated for each weekly setting and expressed as the percent true fertility.

Calculations and statistics. - In order to calculate the percent replenishment of d. deferens semen it was assumed that $(a)$ the ejaculated semen was not diluted by transparent fluid, and (b) that the residual semen in the $d$. deferens after 5 successive ejaculations is a constant fraction of the ejaculated semen volume. Therefore, a Residual Semen Factor $\left(\mathrm{RSF}_{0}\right)$ was calculated to estimate the residual semen in the $d$. deferens after 5 ejaculations for each bird killed at 0 time (immediately after the fifth successive ejaculation) as follows :

1) $\mathrm{RSF}_{0}=\frac{\mathrm{dd}_{0}}{\sum \mathrm{Ejac}_{0}}$ where $\mathrm{dd}_{0}$ is the volume of semen $(\mathrm{ml})$ in the $\mathrm{d}$. deferens at 0 time ; and $\mathrm{Ejac}_{0}$ is the sum of the volume of semen $(\mathrm{ml})$ in the 5 successive ejaculations. For birds killed 1 to 9 days after 5 successive ejaculations, the mean of the RSF ${ }_{0}\left(R_{S F}\right)$ was used to calculate the semen capacity (SC), an estimate of the semen volume in the $d$. deferens before ejaculation for each bird as follows :

2) $\mathrm{SC}=\sum \mathrm{Ejac}_{0}+\mathrm{RSF}_{\mathrm{m}}\left(\sum \mathrm{Ejac}_{0}\right)$.

The percent replenishment (p. $100 \mathrm{Rep}$ ), an estimate of the d. deferens refilling during Days 1 to 9 after multiple ejaculations was calculated for each bird as follows :

3) p. $100 \operatorname{Rep}=\frac{d_{r}}{S C} \times 100$ where $d_{r}$ is the volume of semen $(\mathrm{ml})$ in the $d$. deferens on Days 1 to 9 after the 5 successive ejaculations.

The values for fotal sperm number were substituted for volumes in Equations 1 to 3 and percent replenishment for sperm number calculated.

All data were compared statistically according to the General Linear Model for the analyses of variance and ranked by the Duncan's Multiple Range Test (Barr ef al., 1976).

\section{Results and discussion.}

Successive ejaculations from LW (male and female lines) and SW turkeys shared common semen characteristics (tables 1,2 , and 3 ). With each successive ejaculation the 
semen volume decreased while semen $\mathrm{pH}$ increased, and the increment of $\mathrm{pH}$ between corresponding successive ejaculations was similar for LW and SW males. However, the $\mathrm{pH}$ of the first ejaculate of the LW female line males (7.88) was higher than the $\mathrm{pH}$ of the first ejaculate of the LW male line males (7.48) or SW males (7.48) (tables 1,2

TABLE 1

$\mathrm{pH}$ of semen from Small White furkeys ejaculated 3 times at $30 \mathrm{~min}$ intervals

\begin{tabular}{|c|c|c|c|}
\hline & \multicolumn{3}{|c|}{ Semen $\mathrm{pH}$ (ejaculate) $\left(^{1}\right)$} \\
\hline & First & Second & Third \\
\hline $\begin{array}{l}\text { Trial } 1 \ldots \ldots \\
\text { Trial } 2 \ldots \ldots\end{array}$ & 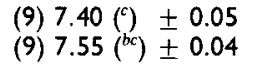 & $\begin{array}{l}(10) 7.57\left({ }^{b c}\right) \pm 0.04 \\
(10) 7.61\left({ }^{b c}\right) \pm 0.03\end{array}$ & $\begin{array}{l}(10) 7.70\left(^{a b}\right) \pm 0.06 \\
(10) 7.90\left(^{a}\right) \pm 0.13\end{array}$ \\
\hline
\end{tabular}

(1) Values are means \pm SEM for the number of observations in parentheses.

All means were compared with each other and means with no superscript lefter in common differ significantly $(P<0.05)$.

TABLE 2

Semen volume, sperm concentration, and semen $\mathrm{pH}$ from Large White turkeys (male line) ejaculated 3 times at 60 min intervals

\begin{tabular}{|c|c|c|c|}
\hline & \multicolumn{3}{|c|}{ Ejaculate $\left({ }^{1}\right)$} \\
\hline & First & Second & Third \\
\hline $\begin{array}{l}\text { Volume }(\mathrm{ml}) \ldots \ldots \ldots \\
\text { Concentration } \\
\left(\text { sperm } \times 10^{9}\right) \ldots \ldots \ldots \\
\mathrm{pH} \ldots \ldots \ldots \ldots \ldots \ldots \ldots\end{array}$ & $\begin{array}{l}\text { (18) } 0.29\left(^{a}\right) \pm 0.04 \\
(16) 5.11\left(^{a}\right) \pm 0.33 \\
\text { (17) } 7.48\left(^{a}\right) \pm 0.09\end{array}$ & $\begin{array}{l}\text { (18) } 0.20\left(^{a}\right) \pm 0.03 \\
(14) 5.20\left(^{a}\right) \pm 0.39 \\
(16) 7.65\left(^{a}\right) \pm 0.07\end{array}$ & $\begin{array}{r}\text { (18) } 0.08\left(^{b}\right) \pm 0.02 \\
(5) 3.84\left(^{b}\right) \pm 0.40 \\
\text { (17) } 7.94\left(^{b}\right) \pm 0.07\end{array}$ \\
\hline
\end{tabular}

( $\left.{ }^{1}\right)$ Values are means \pm SEM for the number of observations in parentheses. Within each row means with no superscript letter in common differ significantly $(P<0.05)$.

TABLE 3

Semen volume, sperm motility, and semen $\mathrm{pH}$ from Large White furkeys (female line) ejaculated 5 times at $30 \mathrm{~min}$ intervals

\begin{tabular}{|c|c|c|c|c|c|c|c|}
\hline & \multirow[b]{2}{*}{$N$} & \multicolumn{6}{|c|}{ Ejaculate } \\
\hline & & First & Second & Thir & & Fourth & Fifth \\
\hline \multicolumn{8}{|l|}{ Volume (ml) } \\
\hline Trial $1 . .$. & 23 & $0.27\left(^{a}\right) \pm 0.02$ & $0.11\left(^{b}\right) \pm 0.02$ & $0.06\left(^{c}\right)$ & \pm 0.01 & $0.09\left(^{b c}\right) \pm 0.01$ & $0.02\left(^{d}\right) \pm 0.01$ \\
\hline Trial $2 \ldots \ldots$ & 24 & $0.30\left({ }^{a}\right) \pm 0.03$ & $0.13\left({ }^{b}\right) \pm 0.01$ & $0.05\left(^{(}\right)$ & \pm 0.01 & $0.04(c) \pm 0.01$ & $0.04\left(^{(\mathcal{c})} \pm 0.01\right.$ \\
\hline \multicolumn{8}{|l|}{ Motility (Score) } \\
\hline Trial $1 \ldots \ldots$ & $17-23$ & $3.4\left({ }^{a b}\right) \pm 0.19$ & $3.8\left(\left(^{a}\right) \pm 0.22\right.$ & $3.6\left(^{a b}\right)$ & \pm 0.21 & $3.0\left({ }^{b c}\right)$ & $2.4\left(^{(}\right) \pm 0.33$ \\
\hline $\mathrm{pH}^{\text {Trial } 2 \ldots . . .}$ & $\mathrm{pH}$ & $3.3\left({ }^{a b}\right) \pm 0.18$ & $3.9\left(^{a}\right) \pm 0.19$ & $\left.3.1^{(b)}\right)^{\prime}$ & \pm 0.25 & $2.4\left(^{(}\right) \pm 0.30$ & $2.2\left(^{c}\right) \pm 0.33$ \\
\hline Trial 1. & $6-23$ & $7.86(c) \pm 0.05$ & $8.02\left(^{b}\right) \pm 0.06$ & & \pm 0.07 & $8.16\left(^{a b}\right)+0.05$ & \\
\hline Trial 2. & $8-24$ & $7.89\left(^{c}\right) \pm 0.04$ & $8.13\left(b^{b} \pm 0.04\right.$ & $8.24\left(^{a b}\right)$ & \pm 0.04 & $8.37\left(^{a}\right) \pm 0.06$ & $8.31\left(^{a}\right) \pm 0.06$ \\
\hline
\end{tabular}

$N=$ the number of observations.

Within each row means $( \pm S E M)$ with no superscript letter in common differ significantly $(P<0.05)$.

Trial 1 was conducted in March-April, 1979. Trial 2 in March-April, 1980. 
and 3). The differences in the $\mathrm{pH}$ of the first ejaculates may represent line differences in semen character. Alternatively, these differences may reflect the addition of variable amounts of transparent fluid to the semen at the time of ejaculation.

Nishiyama (1951) found the volume of transparent fluid in chicken semen to be highly variable between males, and as the amount of transparent fluid in the ejaculate increased the $\mathrm{pH}$ of the ejaculate increased. The $\mathrm{pH}$ of dense white semen was 7.2 (Nishiyama, 1955), semen diluted significantly with transparent fiuid was 7.9 (Nishiyama, 1952), and transparent fluid collected from vasectomized chickens was 8.6 (Nishiyama and Fijishima, 1961). Assuming the $\mathrm{pH}$ of the transparent fluid from the turkey is the same as for the chicken then the increase in semen $\mathrm{pH}$ with successive ejaculations appears to be due to an increase in transparent fluid in the ejaculated semen. However, if the ratio of transparent fluid to semen does increase, it is not reflected in semen $\mathrm{pH}$ and sperm concentration until the third successive ejaculate at which time a drop in both parameters are noted (LW male line, table 2). Wilcox (1958) demonstrated that a decrease in $\mathrm{pH}$ is brought about by the metabolic activity of the sperm and conversely an elevation in $\mathrm{pH}$ might be explained by lower numbers of sperm in the ejaculate, a lower motility rate, and a corresponding higher proportion of seminal plasma (Snapir and Perek, 1964). We noted a decrease in motility and an increase of $0.34 \mathrm{pH}$ unit between the first and fourth semen collection ( $90 \mathrm{~min}$, table 3 ).

The $\mathrm{pH}$ of ejaculated semen can be further assessed by comparing the $\mathrm{pH}$ of the first ejaculate ( 0 time, tables 1,2 , and 3 ) with the $\mathrm{pH}$ of semen from the receptaculum or distal segments of the $d$. deferens (tables 4 and 5). It can be assumed that the $\mathrm{pH}$ of the ejaculate would be the same as the $\mathrm{pH}$ of semen in the distal segment if the ejaculate were not diluted by transparent fluid. However, the $\mathrm{pH}$ of the first ejaculate was 0.14 unit higher than the $\mathrm{pH}$ of semen from the receptaculum of $\mathrm{SW}$ turkeys (tables 1 and 4) and LW turkeys (male line, tables 2 and 4) and 0.20 unit higher than the $\mathrm{pH}$ of semen from the distal segment of the $d$. deferens of LW turkeys (female line, tables 3 and 5).

The $\mathrm{pH}$ of semen from the receptaculum/distal segment was lower than the middle and proximal segments for the three types of turkeys (table 4 ; table 5 , no ejaculation).

TABLE 4

$\rho H$ of semen from $d$. deferens segments from Small White and Large White (male line) turkeys

Semen $\mathrm{pH}$ in $\mathrm{d}$. deferens segments $\left({ }^{1}\right)$

\begin{tabular}{|c|c|c|c|c|}
\hline Turkeys & Proximal & Middle & Distal & Receptaculum \\
\hline $\begin{array}{l}\text { Small White . . . . . . . } \\
\text { Large White....... }\end{array}$ & $\begin{array}{l}(17) 7.78\left({ }^{b}\right) \pm 0.04 \\
(17) 7.91\left(^{a}\right) \pm 0.06\end{array}$ & $\begin{array}{l}(17) 7.64\left(^{c}\right) \pm 0.05 \\
(17) 7.69\left(^{b c}\right) \pm 0.04\end{array}$ & $\begin{array}{l}(17) 7.38\left({ }^{d}\right) \pm 0.04 \\
(15) 7.47\left(^{d}\right) \pm 0.04\end{array}$ & $\begin{array}{l}(17) 7.23\left(^{e}\right) \pm 0.04 \\
(15) 7.34\left(^{d e}\right) \pm 0.06\end{array}$ \\
\hline
\end{tabular}

( $\left.{ }^{1}\right)$ Values are means for the number of observations in parentheses.

All means were compared with each other and means with no superscript letter in common differ significantly $(P<0.05)$

The $\mathrm{pH}$ increased progressively about 0.22 unit from distal to middle and from the middle to proximal segments. As the semen from the more proximal segments of the d. deferens moves down the $d$. deferens and enters the ejaculate, the ejaculate could be expected to have a $\mathrm{pH}$ increase of 0.5 unit with exhaustive ejaculation. This estimation 
TABLE 5

Semen $\mathrm{pH}$ from $d$. deferens from Large Whife furkeys (female line) before and after 5 successive ejaculations

\begin{tabular}{|c|c|c|c|}
\hline & \multicolumn{3}{|c|}{ Semen $\mathrm{pH}$ in $\mathrm{d}$. deferens segments } \\
\hline & Proximal & Middle & Distal \\
\hline $\begin{array}{l}\text { No ejaculation........ } \\
\text { Hours after ejaculation } \\
\qquad \begin{array}{c}24 \\
72\end{array}\end{array}$ & $\begin{array}{l}(18) 8.21\left({ }^{a b}\right) \\
(20) 8.29\left(^{a}\right) \\
(16) 8.27\left(^{a}\right)\end{array}$ & $\begin{array}{l}\text { (18) } 7.92\left({ }^{d e}\right) \\
(17) 8.02\left({ }^{c d}\right) \\
\text { (17) } 8.09\left({ }^{b c}\right)\end{array}$ & $\begin{array}{l}(18) 7.67\left(^{f}\right) \\
(12) 7.99\left(^{c d e}\right) \\
(17) 7.86\left(^{e}\right)\end{array}$ \\
\hline
\end{tabular}

Number of observations in parentheses.

All means were compared with each other and means with no superscript letter in common differ significantly $(P<0.05)$.

agrees with the change in $\mathrm{pH}$ between the first ejaculate and the fifth ejaculate for $\mathrm{LW}$ tijrkeys (tables 2 and 3). However, as the semen from the proximal segment moves down the $d$. deferens the $\mathrm{pH}$ of the semen may decrease because of changes in the luminal milieu derived from epithelial secretory activity or as a result of changing metabolic by-products by the sperm in response to changing substrates or further maturation (or aging). Further studies are necessary to determine if $\mathrm{pH}$ could decrease in the d. deferens within the $120 \mathrm{~min}$ used for the multiple ejaculations.

Sperm from all segments of the $d$. deferens were actively motile regardless of the number of previous ejaculations (table 6). The sperm, however, were diluted with an

TABLE 6

Semen volume and motility of sperm in d. deferens segments from Large White turkeys (female line) before and after 5 successive ejaculations

\begin{tabular}{|c|c|c|c|c|c|c|}
\hline & $\mathrm{ml}$ & $\begin{array}{l}\text { Semen volume } \\
\text { d. deferens seg }\end{array}$ & ents & of sperm & $\begin{array}{l}\text { otility score } \\
\text { om d. defere }\end{array}$ & segments \\
\hline & Proximal & Middle & Distal & Proximal & Middle & Distal \\
\hline $\begin{array}{c}\text { No ejaculation } \\
\text { Hours after } \\
\text { ejaculation } \\
24 \\
72\end{array}$ & $\begin{array}{l}\text { (18) } 0.13\left({ }^{(d)}\right) \\
\text { (12) } 0.07\left(^{d d}\right) \\
\text { (17) } 0.08\left(^{(d)}\right)\end{array}$ & $\begin{array}{r}\text { (9) } 0.15\left({ }^{(b c}\right) \\
\text { (17) } 0.17\left(^{h c}\right)\end{array}$ & $\begin{array}{l}\text { (18) } 0.32\left({ }^{a}\right) \\
(12) 0.19\left({ }^{b c}\right) \\
(17) 0.23\left(^{b}\right)\end{array}$ & $\begin{array}{l}\text { (13) } 2.2\left(^{(")}\right) \\
\text { (17) } 2.9\left(^{(")}\right.\end{array}$ & $\begin{array}{l}\text { (17) } 2.8\left({ }^{(a}\right) \\
\text { (17) } 2.7\left(^{(a)}\right.\end{array}$ & $\begin{array}{l}\text { (18) } 2.1\left(^{a}\right) \\
(12) 2.2\left(^{a}\right) \\
(17) 2.8\left(^{a}\right)\end{array}$ \\
\hline
\end{tabular}

( $\left.{ }^{1}\right)$ Score of $2=20-39$ p. 100 and $3=40-69$ p. 100 of the sperm were progressively motile.

Number of observations in parentheses.

Within a semen measurement all means were compared with each other and means with no superscript letter in common differ significantly $(P<0.05)$.

equal volume of diluent and examined at room temperature. Sperm motility may have been activated by either the addition of the diluent and/or the lowered temperature. We examined a limited number of undiluted semen samples from the $d$. deferens and saw evidence of motile sperm around the periphery of the drop.

The $\mathrm{d}$. deferens contained $0.32,0.22$, and $0.13 \mathrm{ml}$ semen in the distal, middle, and proximal segments respectively (table 6, no ejaculation). Affer 5 successive ejaculations $0.08 \mathrm{ml}$ (12 p. 100 of the total volume of the 5 ejaculates) remained in the $d$. deferens. Seventy-two hrs after the 5 successive ejaculations the volume of semen in the $d$. defe- 
rens had not refilled to the volume of $d$. deferens with no ejaculation (table 6). Also, at $72 \mathrm{hrs}$ after the last ejaculation the $\mathrm{pH}$ of the semen in the distal portion of the $\mathrm{d}$. deferens was higher than the $\mathrm{pH}$ of semen from the distal portion of the $\mathrm{d}$. deferens that had no ejaculation (table 5). The volume of semen in the $d$. deferens was not replenished until 4-5 days after the 5 successive ejaculations (table 7). However by calculation, the

TABLE 7

Replenishment of $d$. deferens semen after 5 successive ejaculations

\begin{tabular}{ccccc}
\hline $\begin{array}{c}\text { Days after } \\
\text { ejaculation }\end{array}$ & $\begin{array}{c}\text { Volume } \\
(\mathrm{ml})\end{array}$ & $\begin{array}{c}\text { Total sperm } \\
\left(\times 10^{\circ}\right)\end{array}$ & \multicolumn{2}{c}{ Calculated p. 100 replenishment } \\
\hline 1 & 0.40 & 3.72 & 49 & Sperm \\
2 & 0.31 & 3.20 & 38 & 53 \\
3 & 0.48 & 5.07 & 57 & 98 \\
4 & 0.51 & 5.19 & 65 & 83 \\
5 & 0.85 & 8.35 & 113 & 138 \\
6 & 0.75 & 8.02 & 93 & 118 \\
9 & 0.72 & 9.84 & 106 & 143 \\
\hline
\end{tabular}

total number of sperm in the $d$. deferens were replenished by the third day. de Reviers (1975) estimated a daily sperm production rate of $2 \times 10^{9} \mathrm{sperm}$ in the chicken and concluded that the extra gonadal sperm reserve (excurrent duct system) represents the equivalent of 3.5 days of daily sperm production. de Reviers' estimate of 3.5 days for the cock agrees well with our calculated estimate of 3 days for replenishment of sperm in the turkey.

Table 8 compares the fertility of the first and third ejaculate and $d$. deferens semen before and 24 and 72 hrs after exhaustive ejaculations. Fertility of the third ejaculate which was presumably diluted with transparent fluid, was the same as the fertility of the

TABLE 8

Ferfility of ejoculated and d. deferens (D.D.) semen

\begin{tabular}{|c|c|c|c|}
\hline \multirow{2}{*}{$\begin{array}{l}\text { Semen } \\
\text { Source }\end{array}$} & \multirow{2}{*}{ Collection time } & \multicolumn{2}{|c|}{ p. 100 Fertility } \\
\hline & & Trial 1 & Trial 2 \\
\hline $\begin{array}{l}\text { 1st Ejac. } \\
\text { 3rd Ejac. } \\
\text { D. D. } \\
\text { Prox. D. D. } \\
\text { Dist. D. D. } \\
\text { D. D. } \\
\text { D. D. } \\
\text { Prox. D. D. } \\
\text { Dist. D. D. } \\
\text { D. D. } \\
\text { D. D. } \\
\text { Prox. D. D. } \\
\text { Dist. D. D. }\end{array}$ & $\begin{array}{c}\text { Before Ejac. } \\
\text { Before Ejac. } \\
\text { Before Ejac. } \\
90 \text { min. Post-5X Ejac. } \\
24 \text { hr. Post-5X Ejac. } \\
24 \mathrm{hr} \text {. Post-5X Ejac. } \\
24 \text { hr. Post-5X Ejac. } \\
48 \text { hr. Post-5X Ejac. } \\
72 \mathrm{hr} \text {. Post-5X Ejac. } \\
72 \mathrm{hr} \text {. Post-5X Ejac. } \\
72 \mathrm{hr} \text {. Post-5X Ejac. }\end{array}$ & $\begin{array}{l}96\left(^{(a)}\right. \\
- \\
92\left(^{a b}\right) \\
- \\
84\left(^{b c}\right) \\
82(c) \\
- \\
92\left(^{a b}\right) \\
88\left(^{a b c}\right) \\
-\end{array}$ & $\begin{array}{c}76\left(^{(d)}\right) \\
66\left(^{d}\right) \\
- \\
88\left(^{a b}\right) \\
83\left(^{b c}\right) \\
- \\
78\left(^{b c d}\right) \\
94\left(^{(a)}\right) \\
- \\
\left.73 \overline{(c d}^{(d)}\right) \\
79\left(^{b c d}\right)\end{array}$ \\
\hline
\end{tabular}

Within each trial means with no superscript letter in common differ significantly $(p<0.05)$. 
first ejaculate. Our data indicate that transparent fluid was not excessively detrimental to the diluted semen which agrees with observations by Nishiyama, Ogawa and Nakanishi (1971). Semen from the entire d. deferens (Trial 1) and both the proximal and distal d. deferens (Trial 2) had fertilizing capacity equal to or better than the first ejaculate. Although the fertilizing capacity of $d$. deferens semen collected $90 \mathrm{~min}$ and 24 hrs after exhaustive ejaculations decreased slightly in Trial 1, there was no decrease in the $24 \mathrm{hr}$ collection in Trial 2. Saeki and Brown (1962) reported a higher fertility from undiluted posterior $d$. deferens semen than from anterior $d$. deferens semen, and the undiluted ejaculated semen had a higher fertilizing ability than the posterior $d$. deferens. However, diluted $d$. deferens semen had fertilizing capacity equal to undiluted ejaculated semen (Saeki and Brown, 1962). In our study all of the semen samples were diluted before insemination and a constant number of sperm inseminated. The possibility still exists that diluting $d$. deferens semen increased its fertilizing capacity.

Our observations indicate that semen removed from different segments of the d. deferens has a wide $\mathrm{pH}$ range, and upon dilution with extender has sperm which are motile and fertile. In addition, based on our calculations turkey males require about 3 days to replenish their sperm reserves after successive ejaculations. However, semen acquired from the d. deferens segments 24 and $48 \mathrm{hrs}$ after successive ejaculations is fertile.

Workshop on "Avian male reproduction » Nouzilly, France, June 1980.

Résumé. Ce travail a été fait pour estimer : a) le $\mathrm{pH}$ et la motilité du sperme prélevé dans les canaux déférents de coqs au repos sexuel depuis une semaine; $b$ ) le $\mathrm{pH}$, la motilité et la concentration en spermatozoïdes du sperme après 3 à 5 éjaculations successives espacées de 30 à $60 \mathrm{~min}$; c) le taux de réplétion en sperme dans les canaux déférents ef la fécondance de ce sperme après vidange des canaux déférents par des éjaculations successives.

Chez les dindons Large et Small White, le $\mathrm{pH}$ du sperme diminue progressivement du segment proximal du canal déférent vers la vésicule spermatique terminale. Les spermatozoïdes de tous les segments du canal déférent sont mobiles. Après éjaculations multiples, le $\mathrm{pH}$ des éjaculats successifs augmente. La concentration en spermatozoïdes du sperme est la même dans le premier et le second éjaculat, mais elle est réduite dans le troisième. Après 5 éjaculats successifs, il reste en moyenne $80 \mu \mathrm{l}$ de sperme dans le canal déférent, soit 12 p. 100 du volume total des 5 éjaculats. Le volume de sperme normalement contenu dans les canaux déférents est restauré en 4.5 jours ef le nombre de spermatozoïdes en 3 jours.

Avant éjaculation, la fécondance du sperme des canaux déférents proximaux et distaux est la même que celle du premier éjaculat. Après éjaculations multiples, la fécondance du troisième éjaculat est légèrement moindre que celle du premier éjaculat. La fécondance du sperme récolté à partir du canal déférent 24 h après éjaculations multiples est égale ou inférieure à la fécondance initiale. II n'y a plus de différence $72 \mathrm{~h}$ après éjaculations multiples.

\section{References}

BARR A. J., GOODNIGHT J. H., SALL J. P., HELWIG J. T., 1976. A Users Guide to SAS 76. Sparks Press, Raleigh, N. C.

COOPER D. M., 1977. Artificial insemination, 305. In GORDON R. F., Poultry Diseases Baillere Tindall, London, England. 
DE REVIERS M., 1975. Sperm transport and survival in male birds, 10-16. In The biology of spermatozoa, INSERM Int. Symp., Nouzilly 1973, Karger, Basel.

LORENZ F. W., WILSON N. E., ASMUNDSON V. S., 1955. Relation of frequency of collection to amount of semen obtained from turkey males. Poultry Sci., 34, 634-639.

MCCARTNEY M. G., CHAMBERLIN V. D., CARTER R. D., WYNE J. W., 1958. Effect of frequency of semen collection on fertility, hatchability and spermatozoa concentration in the furkey. Poultry Sci., 37, 363-366.

NISHIYAMA H., 1951. Studies on the physiology of reproduction in the male fowl III. On the addition of transparent fluid to the cock's semen. Sci. Bull. Fac. Agr. Kyushu Univ., 13, 377-387.

NISHIYAMA H., 1952. On the hydrogen ion concentration of the transparent semen in the fowl. Sci. Bull. Fac. Agr. Kyushu Univ., 12, 277.

NISHIYAMA H., 1955. Studies on the accessory reproductive organs in the cock. J. Fac. Agr. Kyushu Univ., 10, 277-305.

NISHIYAMA H., FUJISHIMA T., 1961. On the ejection of the accessory reproduciive fluid of the cock during natural copulation. Mem. Foc. Agr. Kagoshima Univ., 4, 27-42.

NISHIYAMA H., OGAWA K., NAKANISHI Y., 1971. Studies on the artificial insemination in the domestic fowl. III. Sperm concentration of semen al collection and sperm-quality of the semen. Mem. Fac. Agr. Kagoshima Univ., 8, 355-366.

SEXTON T. J., 1980. A new poultry semen extender. 5. Relationship of diluent components to cytotoxic effects of dimethylsulfoxide on turkey spermatozoa. Poultry Sci., 59, 1142-1144.

SAEKI Y., BROWN K. I., 1962. Fertilizing ability and laboratory evaluation of ejaculated and vasa deferentia semen in turkeys. Poultry Sci., 41, 905-909.

SNAPIR N., PEREK M., 1964. Assessment of cock semen quality by determination of the change in its initial $\mathrm{pH}$ over a given period of time. Poultry Sci., 43, 478-481.

WILCOX F. H., 1958. Changes in the pH of semen of the domestic cock as affected by temperature and frequency of collection. Poultry Sci., 37, 444-449. 